\title{
KEMANDIRIAN DAN HASIL BELAJAR SISWA PADA MATA PELAJARAN KOMPUTER AKUNTANSI DENGAN MENGGUNAKAN MEDIA TUTORIAL MYOB BERBASIS ADOBE CAPTIVATE
}

\author{
Nita Mema \\ PT Karya Agung Megah Jaya, Trenggalek \\ Email: nita.mema@ymail.com
}

\begin{abstract}
Adobe Captivate based-MYOB tutorial media is one of the alternative media to conduct individual learning. This research aims at examining the students' independency and study performance on Accounting Computer Subject by using Adobe Captivate based-MYOB tutorial media. This was a quasi-experimental research conducted in SMK Negeri 1 Boyolangu. The research used Purposive sampling technique. Thirty six students of XI Ak 2 class was decided as the sample. This class was divided into two groups: experiment group and control group. Experiment group was given Adobe Captivate based-MYOB tutorial media, while control group was taught by conventional method. Instrument used in this research were test and questionnaire. Test was used to measure the learning result while questionnaire was used to measure the students' independency in learning. The research results show that Adobe Captivate based-MYOB tutorial media enhance students' independency and study performance. Therefore, it was recommended for teachers to use such tutorial media in Accounting Computer course to enhance the students' independency and study performance.
\end{abstract}

Key words: Adobe Captivate based-tutorial media, Learning Independency, Learning Performance.

\begin{abstract}
Abstrak: Penggunaan media tutorial $M Y O B$ berbasis Adobe Captivate merupakan salah satu alternatif dalam penyelenggaraan pembelajaran individual. Penelitian ini bertujuan untuk mengetahui perbedaan kemandirian dan hasil belajar siswa pada Mata Pelajaran Komputer Akuntansi dengan menggunakan media tutorial $M Y O B$ berbasis Adobe Captivate. Penelitian ini merupakan penelitian eksperimen semu (quasi experimental) yang dilaksanakan di SMK Negeri 1 Boyolangu, Tulungagung. Pengambilan sampel dilakukan dengan teknik Sampling Purposive. Kelas XI Ak 2 berjumlah 36 siswa ditetapkan sebagai sampel. Kelas ini dibagi menjadi dua kelompok, yaitu kelompok eksperimen dan kelompok kontrol dengan jumlah masing-masing 18 siswa. Kelompok eksperimen diberi media tutorial MYOB berbasis Adobe Captivate, sedangkan kelompok kontrol diajar dengan metode konvensional. Instrumen yang digunakan adalah tes dan angket. Tes digunakan untuk mengukur hasil belajar, sedangkan angket digunakan untuk mengukur kemandirian belajar. Hasil penelitian menunjukkan bahwa media tutorial $M Y O B$ berbasis Adobe Captivate dapat meningkatkan kemandirian dan hasil belajar siswa. Oleh karena itu, disarankan bagi guru untuk menggunakan media tutorial ini dalam pembelajaran Komputer Akuntansi untuk meningkatkan kemandirian dan hasil belajar siswa.
\end{abstract}

Kata kunci: Media Tutorial $M Y O B$ berbasis Adobe Captivate, Kemandirian Belajar, Hasil Belajar 
Media mempunyai kedudukan penting dalam proses belajar mengajar, tidak hanya sekadar alat bantu mengajar, tetapi merupakan bagian integral dalam proses belajar mengajar. Menurut teori belajar Koneksionisme (Connectionism) yang dipelopori oleh Edward L. Thorndike, belajar adalah hubungan antara stimulus dan respons (S-R) (Syah, 2010:103). Stimulus ialah suatu keadaan yang diberikan oleh guru kepada siswa. Stimulus bisa berupa motivasi, metode pengajaran, reward dan punishment, buku, media pembelajaran, alat peraga, pedoman kerja, atau cara-cara tertentu, untuk membantu belajar siswa. Dengan pemberian stimulus yang berupa media pembelajaran, siswa bisa merespons dengan sikap ketertarikan maupun sikap yang biasa saja. Apabila siswa tertarik, maka ia akan termotivasi untuk belajar melalui media tersebut.

Gagne \& Briggs mengemukakan bahwa media bisa merangsang siswa untuk belajar (Sadiman, 2010:6). Hal serupa juga diungkapkan Hamalik (2008:200), bahwa media pembelajaran membangkitkan keinginan dan minat yang baru, membangkitkan motivasi dan rangsangan kegiatan belajar, dan bahkan membawa pengaruh-pengaruh psikologis terhadap siswa. Selain itu, media juga dapat mencegah kebosanan serta memperkuat pemahaman pada materi yang diajarkan sehingga kesulitan belajar siswa teratasi (Miarso, 2005:459). Selain kaitannya dengan motivasi, pentingnya media pembelajaran juga berkaitan dengan kemandirian belajar. Seperti yang disampaikan Arsyad (2007:26), bahwa media pembelajaran memungkinkan siswa untuk belajar sendiri-sendiri sesuai dengan kemampuan dan minatnya.

Dewasa ini, terdapat berbagai macam media pembelajaran yang digunakan dalam pendidikan formal maupun non formal. Arsyad (2007:29) mengelompokkan media pembelajaran menjadi empat, yaitu media teknologi cetak, media teknologi audio-visual, media teknologi berbasis komputer, dan media gabungan teknologi cetak dan komputer. Salah satu jenis media teknologi berbasis komputer ialah media tutorial. Media tutorial adalah media yang berisi panduan tentang cara menjelaskan sesuatu, baik materi pembelajaran atau pelatihan (training) maupun proses pengoperasian suatu sistem (hardware \& software) (Aripin, 2009:1).

Media tutorial merupakan media pembelajaran interaktif berbasis komputer yang dirancang untuk dipakai siswa secara individual (belajar mandiri). Saat siswa mengaplikasikan program ini, ia diajak untuk terlibat secara auditif, visual, dan kinetik, sehingga dengan pelibatan ini dimungkinkan informasi atau pesannya mudah dimengerti (Munadi, 2010:152). Karena dirancang khusus untuk pembelajaran mandiri, maka kebutuhan siswa secara individual bisa terakomodasi, termasuk bagi siswa yang lamban dalam 
menerima pelajaran. Dengan terakomodasinya kebutuhan siswa, maka siswa akan termotivasi untuk terus belajar.

Media tutorial juga dapat meningkatkan hasil belajar siswa. Menurut Munadi (2010:152), penggunaan media tutorial cukup efektif meningkatkan hasil belajar peserta didik. Penggunaan media pembelajaran melalui komputer (media tutorial) dalam pembelajaran akan membuat kegiatan pembelajaran berlangsung secara tepat guna (efektif) dan berdaya guna (efisien) sehingga hasil belajar siswa dapat ditingkatkan (Wena, 2009:204).

Pada Sekolah Mengengah Kejuruan (SMK) khususnya Kompetensi Keahlian Akuntansi terdapat mata pelajaran Komputer Akuntansi layaknya di perguruan tinggi. Dalam dunia pendidikan, program Komputer Akuntansi yang biasanya dipakai adalah program MYOB. MYOB merupakan kependekan dari Mind Your Own Business, yang digunakan sebagai aplikasi pengotomatisasian pembukuan yang mudah digunakan dan mampu menampilkan laporan keuangan secara lengkap, cepat dan akurat. $M Y O B$ memiliki fungsifungsi yang terdefinisi dengan sangat jelas. Terdapat beberapa gabungan modul yang disajikan untuk mengelola data akuntansi sehingga pengguna (user) hanya perlu mengoperasikannya. Diperlukan tingkat pemahaman dan ketelitian yang tinggi untuk mengoperasikan $M Y O B$. Kesulitan yang biasanya dialami oleh siswa ialah saat memasukkan transaksi ke dalam Jurnal maupun jendela (windows) lainnya. Kesulitan ini lebih mengarah pada hal-hal yang bersifat teknis. Untuk itu, diperlukan media pembelajaran untuk memahami pengoperasian $M Y O B$ sebagai pelengkap dari penjelasan guru.

Media yang relevan dengan pembelajaran $M Y O B$ ialah media tutorial berbasis komputer. Media tutorial sesuai untuk mengajarkan suatu proses atau tahapan seperti pengoperasian $M Y O B$. Ada beberapa Software untuk membuat media tutorial $M Y O B$, salah satunya Adobe Captivate. Media tutorial $M Y O B$ berbasis Adobe Captivate berisi panduan lengkap dalam mengoperasikan $M Y O B$ yang disertai dengan instrumen audio dan visual. Media tutorial $M Y O B$ berbasis Adobe Captivate bisa dimanfaatkan oleh siswa di dalam kelas, sementara guru menjadi fasilitator. Siswa bisa memahami cara mengoperasikan MYOB dengan media ini tanpa penjelasan dari guru. Media ini juga bisa dipelajari siswa di luar kelas atau dibawa pulang, sehingga siswa bisa belajar mandiri tanpa bantuan dari guru atau orang lain.

Media tutorial diprediksi juga bisa meningkatkan hasil belajar siswa. Hasil penelitian Pujiantoro (2011) menyimpulkan bahwa siswa mengalami peningkatan hasil belajar dengan menggunakan media tutorial berbasis multimedia interaktif. Penelitian serupa juga dilakukan oleh Erfan (2009) dengan kesimpulan bahwa hasil belajar siswa sesudah menggunakan media 
pembelajaran tutorial Corel Draw lebih tinggi daripada siswa sebelum menggunakan media pembelajaran tersebut. Hasil belajar siswa Kelas IX MTs. Wahid Hasyim 02 Dau Kabupaten Malang juga meningkat sesudah menggunakan media pembelajaran CD Tutorial Menggunakan Software Camtasia Studio 6.0 (Sidik, 2010).

Penelitian ini dilaksanakan di SMK Negeri 1 Boyolangu, Tulungagung. Siswa yang mendapatkan mata pelajaran Komputer Akuntansi ialah siswa kelas XI dan XII Kompetensi Keahlian Akuntansi. Secara umum hasil belajar siswa kelas XI dan XII pada mata pelajaran Komputer Akuntansi sudah berada di atas Standar Ketuntasan Minimal (SKM). Namun, ratarata hasil belajar kelas XI belum mencapai SKM. Rata-rata nilai ulangan harian kelas XI pada Mata Pelajaran Komputer Akuntansi sebesar 74, sedangkan SKM yang ditetapkan oleh SMK Negeri 1 Boyolangu ialah 75. Pencapaian nilai yang kurang ini dikarenakan pada semester I/Ganjil kelas XI melaksanakan Praktik Kerja Industri (Prakerin), sehingga waktu belajar di sekolah relatif singkat. Media tutorial $M Y O B$ berbasis Adobe Captivate membantu siswa dalam mempelajari pengoperasian $M Y O B$ yang tidak dibatasi oleh ruang kelas atau laboratorium, sehingga kemandirian dan hasil belajar siswa diharapkan bisa meningkat.

Penelitian tentang media pembelajaran pada Mata Pelajaran Komputer Akuntansi, khususnya $M Y O B$ belum pernah dielaborasi oleh peneliti sebelumnya. $M Y O B$ merupakan program Komputer Akuntansi yang menyajikan langkah-langkah dalam membukukan transaksi keuangan. Siswa perlu mereview berulang-ulang agar benar-benar bisa memahami langkah-langkah kerja dalam $M Y O B$. Dalam pembelajaran konvensional guru tidak mungkin mengulang-ulang materi yang telah dijelaskan. Oleh karena itu, diperlukan media pembelajaran yang bisa dimanfaatkan oleh siswa untuk belajar mandiri. Media tutorial $M Y O B$ berbasis Adobe Captivate merupakan media pembelajaran berbasis komputer yang dibuat dengan Software Adobe Captivate yang berisi langkah-langkah mengoperasikan $M Y O B$ dan disertai dengan instrumen audio visual.

Tujuan penelitian ini adalah untuk mengetahui perbedaan kemandirian dan hasil Belajar Siswa pada Mata Pelajaran Komputer Akuntansi dengan Menggunakan Media Tutorial $M Y O B$ Berbasis Adobe Captivate. Secara teoritis, penelitian ini diharapkan bermanfaat untuk menguji keberlakukan teori belajar Koneksionisme (Connectionism) yang dipelopori oleh Edward L. Thorndike, bahwa belajar adalah hubungan antara stimulus dan respons (S-R) (Syah, 2010:103). Stimulus ialah suatu keadaan yang diberikan oleh guru kepada siswa. Stimulus bisa berupa motivasi, metode pengajaran, reward dan punishment, buku, dan media pembelajaran. Dengan pemberian stimulus yang berupa media pembelajaran, siswa bisa merespons dengan sikap ketertarikan maupun sikap yang biasa saja. 
Apabila siswa tertarik, maka ia akan termotivasi untuk belajar melalui media tersebut. Secara praktis, hasil penelitian ini diharapkan dapat digunakan sebagai masukan utamanya bagi guru untuk dapat mengetahui efektivitas penggunaan media tutorial dalam pembelajaran Komputer Akuntansi dalam meningkatkan kemandirian dan hasil belajar siswa.

Untuk menghindari pemaknaan yang kurang sesuai terhadap istilah-istilah dalam penelitian ini, maka perlu ditegaskan definisi operasional berikut. Media tutorial $M Y O B$ berbasis Adobe Captivate adalah media audio visual untuk pembelajaran $M Y O B$ yang dibuat dengan menggunakan Software Adobe Captivate berbentuk tutorial (berisi langkah-langkah membukukan transaksi dengan $M Y O B$ ) yang dikemas dalam bentuk Compact Disk (CD). Kemandirian belajar adalah sikap dan kemampuan siswa yang dapat melakukan aktivitas belajar sendiri tanpa tergantung kepada orang lain. Kemandirian belajar diukur dengan menggunakan tiga indikator, yaitu: (1) Independence (ketidaktergantungan) yang didefinisikan sebagai perilaku yang aktifitasnya diarahkan pada diri sendiri, tidak mengharapkan pengarahan orang lain, dan bahkan mencoba serta menyelesaikan masalahnya sendiri tanpa minta bantuan orang lain, (2) Autonom (menetapkan hak mengurus sendiri) atau disebut juga kecenderungan berperilaku bebas dan original, dan (3) Self Reliance merupakan perilaku yang didasarkan pada kepercayaan diri sendiri (Goodman and Smart dalam Hidayati dan Endang, 2009). Sedangkan hasil belajar adalah suatu hasil yang diperoleh siswa karena adanya aktivitas belajar yang telah dilakukan dan ditandai dengan perkembangan serta perubahan tingkah laku. Hasil belajar yang digunakan dalam penelitian ini adalah nilai siswa pada aspek kognitif.

\section{METODE}

Penelitian ini termasuk penelitian Quasi Experimental Design dengan bentuk Nonequivalent Control Group Design. Disebut Quasi Experimental Design karena mempunyai kelompok kontrol, tetapi tidak dapat berfungsi sepenuhnya untuk mengontrol variabel-variabel luar yang mempengaruhi pelaksanaan eksperimen (Sugiyono, 2010:114). Disebut Nonequivalent Control Group Design karena kelompok eksperimen maupun kelompok kontrol tidak dipilih secara random.

Adapun rancangan penelitiannya digambarkan dengan tabel berikut.

Tabel 1. Rancangan Penelitian

\begin{tabular}{lclc}
\hline Kelompok & Pretest & Treatment & Posttest \\
\hline $\mathrm{KE}$ & $\mathrm{O}_{1}$ & $\mathrm{X}$ & $\mathrm{O}_{2}$ \\
\hline
\end{tabular}




\begin{tabular}{llll}
\hline $\mathrm{KK}$ & $\mathrm{O}_{3}$ & - & $\mathrm{O}_{4}$ \\
\hline
\end{tabular}

Sumber: Sugiyono, 2010:116

Keterangan:

KE : Kelas Eksperimen

KK : Kelas Kontrol

$\mathrm{X}$ : Perlakuan berupa penggunaan media tutorial $M Y O B$ berbasis Adobe Captivate

- $\quad$ : Pembelajaran dengan metode konvensional tanpa menggunakan media tutorial MYOB berbasis Adobe Captivate

$\mathrm{O}_{1}$ : Nilai pretest dan hasil angket kemandirian belajar siswa sebelum perlakuan pada kelas eksperimen

$\mathrm{O}_{2}$ : Nilai posttest dan hasil angket kemandirian belajar siswa sesudah perlakuan pada kelas eksperimen

$\mathrm{O}_{3}$ : Nilai pretest kelas kontrol

$\mathrm{O}_{4} \quad$ : Nilai posttest kelas kontrol

Populasi pada penelitian ini adalah seluruh siswa Kompetensi Keahlian Akuntansi yang sedang menempuh Mata Pelajaran Komputer Akuntansi, yaitu kelas XI Akuntansi SMK Negeri 1 Boyolangu, Tulungagung tahun ajaran 2011/2012. Di SMK Negeri 1 Boyolangu, Tulungagung terdapat tiga kelas Kompetensi Keahlian Akuntansi, yaitu kelas XI Ak 1, XI Ak 2, dan XI Ak 3 dengan jumlah 109 siswa. Sampel adalah bagian dari jumlah dan karakteristik yang dimiliki oleh populasi tersebut (Sugiyono, 2010:118). Teknik sampling yang dipakai adalah Sampling Purposive yaitu teknik penentuan sampel dengan pertimbangan tertentu. Sampel yang digunakan adalah Kelas XI Ak 2 sejumlah 36 siswa, dengan pertimbangan bahwa dua kelas yang lain, yaitu Kelas XI Ak 1 dan XI Ak 3 sedang melaksanakan Praktek Kerja Industri (Prakerin). Kelas XI Ak 2 dibagi menjadi dua kelompok, yaitu kelompok eksperimen dan kelompok control, sehingga masing-masing kelas terdiri dari 18 siswa.I

Dalam penelitian ini, instrumen yang digunakan adalah tes dan kuesioner. Tes digunakan untuk mengukur variabel hasil belajar. Tes yang digunakan ialah tes praktik menyelesaikan siklus akuntansi dengan menggunakan $M Y O B$ Accounting. Untuk soal pretest menggunakan perusahaan jasa, sedangkan soal posttest menggunakan perusahaan dagang. Pada soal terdapat data neraca saldo, daftar nama debitur dan kreditur, serta transaksi selama satu periode. Aspek yang dinilai dalam tes ini ialah Jurnal, Laporan Laba Rugi (Income and Expense), Neraca (Asset, Liability, Equity) dan Daftar Saldo (debitur dan kreditur). Kuesioner digunakan untuk mengukur kemandirian belajar siswa yang telah diberikan media tutorial 
$M Y O B$ berbasis Adobe Captivate. Bentuk kuesioner adalah kuesioner tertutup dengan skala Likert 1-4.

Untuk mendapatkan hasil penelitian yang akurat, dilakukan uji validitas dan reliabilitas terhadap instrumen penelitian. Instrumen tes diuji dengan menggunakan validitas isi (content validity), karena tes berupa soal praktik mengerjakan Siklus Akuntansi dengan menggunakan $M Y O B$ Accounting dan hasilnya valid semua. Sementara untuk menguji validitas instrumen angket digunakan teknik korelasi product moment dengan mengkorelasikan skor setiap butir soal dengan skor total menggunakan SPSS 16.0 for Windows. Hasil analisis menunjukkan bahwa dari 25 item pernyataan angket, hanya 1 (item no 2) yang tidak valid sehingga dihapus dari daftar pernyataan angket. Hasil uji reliabilitas juga menunjukkan bahwa instrumen penelitian reliabel.

Penelitian ini menggunakan teknik pengumpulan data berupa tes dan kuesioner. Tes digunakan untuk melihat hasil belajar siswa sebelum dan setelah diberikan media pembelajaran. Tes ini digunakan untuk mengukur hasil belajar siswa dalam penguasaan dalam mengoperasian $M Y O B$ Accounting dengan metode pembelajaran konvensional maupun dengan pemberian media yang berupa media tutorial $M Y O B$ berbasis Adobe Captivate. Tes ini diberikan kepada siswa pada kelompok kontrol dan kelompok eksperimen. Kuesioner diberikan pada responden sebelum dan setelah diberikan media tutorial $M Y O B$ berbasis Adobe Captivate pada kelompok eksperimen. Hasil pengolahan data dari kuesioner akan dibandingkan antara kemandirian belajar siswa sebelum menggunakan media dan setelah menggunakan media. Kuesioner ini hanya diberikan pada kelompok eskperimen dengan tujuan untuk mengetahui pengaruh perlakuan yang berupa pemberian tutorial $M Y O B$ berbasis Adobe Captivate terhadap kemandirian belajar siswa.

Setelah data terkumpul dan ditabulasikan maka proses selanjutnya adalah menganalisis data tersebut agar dapat diambil suatu kesimpulan dari pemecahan masalah. Kemandirian belajar siswa setelah diberikan media tutorial $M Y O B$ berbasis Adobe Captivate dianalisis dengan menggunakan analisis deskriptif. Untuk mengetahui pengaruh penggunaan media tutorial berbasis Adobe Captivate terhadap kemandirian belajar akan dilakukan uji t-paired sample dengan bantuan program SPSS 16.0 for windows. Sedangkan pengaruh penggunaan media tutorial terhadap hasil belajar akan diuji dengan uji t-independent sample. 


\section{HASIL}

\section{Data Kemampuan Awal Siswa}

Data kemampuan awal siswa diperoleh dari nilai pretest siswa yang dilaksanakan sebelum diberikan perlakuan. Kelas eksperimen mendapatkan perlakuan berupa penggunaan media tutorial $M Y O B$ berbasis Adobe Captivate dalam pembelajaran Komputer Akuntansi, sedangkan kelas kontrol tidak mendapatkan perlakuan, namun hanya diajar secara konvensional tanpa menggunakan media. Nilai terendah untuk kelas eksperimen dan kelas kontrol adalah sama, yaitu 75. Rata-rata data kemampuan awal siswa untuk kelas eksperimen sebesar 77,00 dan untuk kelas kontrol sebesar 77,057. Berdasarkan data tersebut dapat dikatakan bahwa nilai rata-rata kemampuan awal siswa kelas kontrol lebih tinggi daripada kelas eksperimen. Namun perbedaan nilai rata-rata antara kelas eksperimen dan kelas kontrol ini tidak terlalu signifikan. Hal ini juga didukung dengan hasil uji beda rata-rata pretest antara kelas eksperimen dan kelas kontrol dengan signifikansi 0,914. Dengan demikian dapat disimpulkan bahwa kemampuan awal siswa kelas kontrol dan eksperimen memiliki rata-rata yang sama.

\section{Data Kemampuan Akhir Siswa}

Data kemampuan akhir siswa diperoleh dari nilai posttest yang dilaksanakan setelah diberi perlakuan. Kelas kontrol yang tidak mendapatkan perlakuan juga diberi posttest yang hasilnya digunakan untuk dibandingkan dengan kelas eksperimen. Nilai tertinggi dan terendah untuk kelas eksperimen adalah 90 dan 75, sedangkan untuk kelas kontrol adalah 82 dan 76. Rata-rata data kemampuan akhir siswa untuk kelas eksperimen sebesar 82,889 dan untuk kelas kontrol sebesar 78,444. Berdasarkan data tersebut dapat dikatakan bahwa nilai rata-rata data kemampuan akhir siswa kelas eksperimen lebih tinggi daripada kelas kontrol. Hal ini berarti bahwa nilai siswa yang menggunakan media tutorial MYOB berbasis Adobe Captivate lebih baik daripada siswa yang tidak menggunakan media.

\section{Kemandirian Belajar Siswa}

Deskripsi variabel kemandirian belajar siswa diperoleh melalui angket yang diberikan kepada kelas eksperimen yang mendapatkan perlakuan berupa penggunaan media tutorial $M Y O B$ berbasis Adobe Captivate. Siswa dalam kelas kontrol tidak diukur kemandirian belajarnya karena tidak mendapatkan perlakuan. Angket diberikan kepada siswa kelas eksperimen sebelum dan sesudah mendapatkan perlakuan. Hal ini bertujuan untuk mengetahui perbedaan kemandirian belajar siswa sebelum dan sesudah menggunakan media 
tutorial $M Y O B$ berbasis Adobe Captivate. Persentase siswa yang sangat mandiri sebelum menggunakan media tutorial sebesar $22,22 \%$ atau sebanyak 4 siswa, sedangkan sesudah menggunakan media jumlah siswa yang sangat mandiri berubah menjadi 8 siswa atau 44,44\%. Untuk jumlah siswa yang masuk ke dalam kriteria mandiri antara sebelum dan sesudah perlakuan adalah sama, yaitu 6 siswa atau sebesar 33,33\%. Jumlah siswa yang tidak mandiri mengalami penurunan setelah menggunakan media tutorial, yakni dari 8 siswa berkurang menjadi 4 siswa. Hal ini menunjukkan bahwa terdapat perbedaan kemandirian siswa sebelum dan sesudah menggunakan media tutorial MYOB berbasis Adobe Captivate.

\section{Pengujian Asumsi}

Uji asumsi bertujuan untuk mengetahui apakah data hasil penelitian yang telah terkumpul siap untuk diolah dengan teknik analisis yang direncanakan, yaitu uji t. Berdasarkan uji normalitas dan uji homogenitas diketahui bahwa sebaran data normal dan varians data homogen sehingga analisis data selanjutnya dilakukan dengan menggunakan statistik parametric (uji t).

\section{Pengujian Hipotesis}

\section{Perbedaan Kemandirian Belajar Siswa Kelas XI Akuntansi di SMK Negeri 1 Boyolangu} dengan Menggunakan Media Tutorial MYOB Berbasis Adobe Captivate

Dalam penelitian ini paired sample t-test digunakan untuk mengetahui perbedaan kemandirian belajar siswa kelas eksperimen sebelum dan sesudah menggunakan media tutorial $M Y O B$ berbasis Adobe Captivate. Berdasarkan uji t-paired sample diperoleh nilai signifikansi $0,002<0,05$ yang berarti $\mathrm{H}_{0}$ ditolak. Hal ini menunjukkan bahwa terdapat perbedaan kemandirian belajar siswa sebelum dan sesudah menggunakan media tutorial. Dengan demikian dapat disimpulkan bahwa hipotesis pertama yang berbunyi terdapat perbedaan kemandirian belajar siswa kelas XI Akuntansi di SMK Negeri 1 Boyolangu dengan menggunakan media tutorial $M Y O B$ berbasis Adobe Captivate diterima.

\section{Perbedaan Hasil Belajar Siswa Kelas XI Akuntansi di SMK Negeri 1 Boyolangu dengan \\ Menggunakan Media Tutorial MYOB Berbasis Adobe Captivate}

Perbedaan hasil belajar siswa setelah menggunakan media tutorial diketahui dengan cara membandingkan hasil belajar antara kelas kontrol dan kelas eksperimen. Hasil belajar dalam penelitian ini diperoleh dari nilai posttest. Uji yang digunakan ialah independent samples $t$-test. Hasilnya terlihat bahwa nilai Sig. (2-tailed) sebesar 0,000 < 0,05. Berdasarkan data tersebut, berarti $\mathrm{H}_{0}$ ditolak dan $\mathrm{H}_{1}$ diterima. Hal ini berarti terdapat perbedaan hasil 
belajar siswa kelas eksperimen dan kelas kontrol. Kesimpulan yang dapat diambil ialah terdapat perbedaan hasil belajar siswa yang lebih baik dengan menggunakan media tutorial MYOB berbasis Adobe Captivate pada kelas XI Akuntansi di SMK Negeri 1 Boyolangu.

\section{PEMBAHASAN}

\section{Perbedaan Kemandirian Belajar Siswa Kelas XI Akuntansi di SMK Negeri 1}

\section{Boyolangu dengan Menggunakan Media Tutorial MYOB berbasis Adobe Captivate}

Teori belajar Koneksionisme (Connectionism) yang dipelopori oleh Edward L. Thorndike menyatakan bahwa belajar adalah hubungan antara stimulus dan respons (S-R) (Syah, 2010:103). Stimulus ialah suatu keadaan yang diberikan oleh guru kepada siswa. Stimulus bisa berupa motivasi, metode pengajaran, reward dan punishment, buku, dan media pembelajaran. Penggunaan media pembelajaran memungkinkan siswa untuk belajar sendiri meskipun tidak mendengarkan penjelasan dari guru, sehingga akan terbentuk pola belajar yang mandiri. Dengan demikian dapat disimpulkan bahwa respon bisa berupa kemandirian belajar siswa.

Penelitian ini bertujuan untuk mengetahui perbedaan kemandirian belajar siswa yang dikarenakan adanya penggunaan media tutorial $M Y O B$ berbasis Adobe Captivate. MYOB merupakan salah satu program komputer akuntansi yang banyak digunakan dalam dunia pendidikan. $M Y O B$ memiliki fungsi-fungsi yang terdefinisi dengan sangat jelas. Terdapat beberapa gabungan modul yang disajikan untuk mengelola data akuntansi sehingga hanya perlu mengoperasikannya. Diperlukan tingkat pemahaman dan ketelitian yang tinggi untuk mengoperasikan $M Y O B$. Dengan demikian, diperlukan media yang bersifat tutorial untuk membantu siswa memahami langkah-langkah teknis dalam MYOB, untuk melengkapi penjelasan dari guru.

Media tutorial merupakan media pembelajaran interaktif berbasis komputer yang dirancang untuk dipakai siswa secara individual (belajar mandiri). Saat siswa mengaplikasikan program ini, ia diajak untuk terlibat secara auditif, visual, dan kinetik, sehingga dengan pelibatan ini dimungkinkan informasi atau pesannya mudah dimengerti (Munadi, 2010:152). Penelitian ini menggunakan media tutorial untuk program MYOB yang dibuat dengan software Adobe Captivate. Media tutorial MYOB berbasis Adobe Captivate berisi panduan lengkap dalam mengoperasikan $M Y O B$ yang disertai dengan instrumen audio dan visual. Media tutorial $M Y O B$ berbasis Adobe Captivate dirancang untuk belajar mandiri 
dan diharapkan siswa dapat memahami pengoperasian $M Y O B$ tanpa penjelasan dari guru atau bantuan orang lain.

Penelitian ini menggunakan uji t-paired sample untuk mengetahui perbedaan kemandirian belajar siswa sebelum dan sesudah menggunakan media tutorial $M Y O B$ berbasis Adobe Captivate. Berdasarkan hasil analisis data dengan bantuan SPSS 16.0 for Windows diketahui bahwa terdapat perbedaan kemandirian belajar siswa kelas eksperimen sebelum dan sesudah diberi perlakuan. Tingkat kemandirian belajar siswa setelah menggunakan media tutorial $M Y O B$ berbasis Adobe Captivate lebih tinggi daripada sebelum menggunakan media. Hal ini dibuktikan dengan adanya peningkatan jumlah siswa dengan kriteria sangat mandiri, yaitu dari 4 siswa menjadi 8 siswa. Siswa dengan kriteria tidak mandiri juga menurun dari 8 siswa menjadi 4 siswa. Persentase jumlah siswa yang sangat mandiri sebesar $44,44 \%$, dan siswa yang mandiri sebesar $33,33 \%$.

Hasil penelitian ini sejalan dengan teori belajar Koneksionisme (Connectionism) yang menyatakan bahwa belajar adalah hubungan antara stimulus dan respons (S-R). Dalam penelitian ini yang dimaksud dengan stimulus adalah media tutorial $M Y O B$ berbasis Adobe Captivate, sedangkan respon adalah kemandirian belajar siswa. Setelah siswa menerima stimulus yang berupa media, maka akan terjadi suatu reaksi yang mengakibatkan adanya respon. Reaksi tersebut merupakan hubungan antara stimulus dan respon. Hubungan antara stimulus dan respon terjadi dalam diri seseorang yang tidak bisa diamati yang bertalian dengan sistem alat saraf dimana terjadi transformasi perangsang yang diterima melalui alat indera (Nasution, 2010:136).

Dari uraian di atas dapat dipahami bahwa terdapat hubungan antara media tutorial $M Y O B$ berbasis Adobe Captivate (stimulus) dengan kemandirian belajar siswa (respon). Dengan demikian, penggunaan media tutorial dapat meningkatkan kemandirian belajar siswa. Kemandirian belajar siswa dapat terlihat dari ketiga indikator berikut: (1) Independence (ketidaktergantungan) yang didefinisikan sebagai perilaku yang aktifitasnya diarahkan pada diri sendiri, tidak mengharapkan pengarahan orang lain, dan bahkan mencoba serta menyelesaikan masalahnya sendiri tanpa minta bantuan orang lain, (2) Autonom (menetapkan hak mengurus sendiri) atau disebut juga kecenderungan berperilaku bebas dan original, dan (3) Self Reliance merupakan perilaku yang didasarkan pada kepercayaan diri sendiri.

Secara umum, siswa pada kelas eksperimen menunjukkan kemandirian belajar terutama pada dua aspek, yaitu independence (ketidaktergantungan) dan autonom (menetapkan hak mengurus diri). Aspek independence dibagi menjadi dua sikap yaitu ketidaktergantungan terhadap orang lain dan berperilaku berdasarkan inisiatif sendiri. 
Mayoritas siswa pada kelas eksperimen mampu belajar mandiri dengan media tutorial tanpa bantuan orang lain atau guru, serta memiliki motivasi belajar yang berasal dari dalam dirinya sendiri. Sementara dalam aspek autonom, siswa mampu berperilaku disiplin, memiliki rasa tanggung jawab, dan dapat mengontrol dirinya sendiri.

\section{Perbedaan Hasil Belajar Siswa Kelas XI Akuntansi di SMK Negeri 1 Boyolangu dengan Menggunakan Media Tutorial MYOB berbasis Adobe Captivate}

Siswa bisa belajar mandiri dengan menggunakan media tutorial, sehingga diharapkan hasil belajar yang diperoleh juga akan cenderung meningkat. Menurut Munadi (2010:152), penggunaan media tutorial cukup efektif meningkatkan hasil belajar peserta didik. Penggunaan media pembelajaran melalui komputer (media tutorial) dalam pembelajaran akan membuat kegiatan pembelajaran berlangsung secara tepat guna (efektif) dan berdaya guna (efisien) sehingga hasil belajar siswa dapat ditingkatkan (Wena, 2009:204).

Hasil belajar adalah suatu hasil yang diperoleh siswa karena adanya aktivitas belajar yang telah dilakukan dan ditandai dengan perkembangan serta perubahan tingkah laku. Sudjana (2005:22) menyatakan bahwa hasil belajar adalah kemampuan-kemampuan yang dimiliki siswa setelah ia menerima pengalaman belajarnya. Hasil belajar siswa terdiri dari tiga aspek, yaitu kognitif, afektif, dan psikomotor. Dalam penelitian ini hasil belajar siswa hanya diukur berdasarkan aspek kognitif yang diperoleh dari hasil posttest.

Untuk mengetahui perbedaan hasil belajar antara siswa kelas kontrol dan eksperimen, uji yang digunakan adalah Independent Sample T-test. Berdasarkan hasil analisis yang telah dijabarkan dalam bab IV diperoleh hasil bahwa terdapat perbedaan hasil belajar siswa yang diberi perlakuan (kelas eksperimen) dan yang tidak diberi perlakuan (kelas kontrol). Rata-rata nilai kelas kontrol sebesar 78,44, sedangkan kelas ekperimen sebesar 82,89. Perbedaan hasil belajar antara kelas kontrol dan eksperimen ini cukup signifikan.

Hasil penelitian ini mendukung teori belajar Koneksionisme (Connectionism) yang menyatakan bahwa belajar adalah hubungan antara stimulus dan respons (S-R). Dalam penelitian ini yang dimaksud dengan stimulus adalah media tutorial $M Y O B$ berbasis Adobe Captivate, sedangkan respon adalah hasil belajar siswa. Dengan adanya stimulus yang berupa media tutorial, maka siswa akan menampakkan responnya. Respon bisa berupa hasil yang tidak teramati, bisa juga berupa hasil belajar yang dapat diamati. Dengan demikian, terdapat hubungan antara media tutorial $M Y O B$ berbasis Adobe Captivate (stimulus) dengan hasil belajar siswa (respon). 
Hasil penelitian ini juga didukung oleh penelitian sebelumnya yang dilakukan oleh Pujiantoro (2011) yang menyimpulkan bahwa siswa mengalami peningkatan hasil belajar dengan menggunakan media tutorial berbasis multimedia interaktif. Demikian pula penelitian Erfan (2009) yang membuktikan bahwa hasil belajar siswa sesudah menggunakan media pembelajaran tutorial Corel Draw lebih tinggi daripada siswa sebelum menggunakan media pembelajaran tersebut.

Berdasarkan uraian di atas maka dapat disimpulkan bahwa terdapat perbedaan hasil belajar siswa yang lebih baik setelah menggunakan media tutorial $M Y O B$ berbasis Adobe Captivate pada Mata Pelajaran Komputer Akuntansi di SMK Negeri 1 Boyolangu. Adanya pengaruh pemanfaatan media sebagai sumber belajar terhadap hasil belajar siswa dapat diartikan bahwa pemanfaatan media memiliki peranan yang penting dalam kaitannya dengan hasil belajar siswa.

\section{SIMPULAN}

Berdasarkan hasil penelitian dapat diperoleh kesimpulan sebagai berikut. Pertama, terdapat perbedaan kemandirian belajar siswa kelas eksperimen sebelum dan sesudah mendapat perlakuan. Tingkat kemandirian belajar siswa kelas XI Akuntansi di SMK Negeri 1 Boyolangu lebih tinggi setelah menggunakan media tutorial MYOB berbasis Adobe Captivate dalam Mata Pelajaran Komputer Akuntansi. Kedua, terdapat perbedaan hasil belajar antara siswa kelas eksperimen dan kelas kontrol. Hasil belajar siswa lebih baik setelah menggunakan media tutorial $M Y O B$ berbasis Adobe Captivate pada Mata Pelajaran Komputer Akuntansi di SMK Negeri 1 Boyolangu. Meski hasilnya sesuai dengan harapan, namun penelitian ini memiliki keterbatasan yaitu pada pengukuran kemandirian belajar yang hanya dilakukan pada kelas eksperimen, tidak digunakan kelas kontrol sebagai pembanding.

\section{A. Saran}

Berdasarkan kesimpulan dan keterbatasan penelitian yang diambil dalam penelitian ini, maka saran yang dapat diberikan oleh peneliti adalah sebagai berikut. Bagi guru, media tutorial $M Y O B$ berbasis Adobe Captivate dapat meningkatkan kemandirian dan hasil belajar siswa, sehingga guru dapat menggunakan media ini dalam pembelajaran Komputer Akuntansi. Bagi siswa, hendaknya melengkapi buku yang dimiliki dengan media tutorial $M Y O B$ berbasis Adobe Captivate dan memakai media ini dalam pembelajaran Komputer Akuntansi untuk meningkatkan kemandirian dan hasil belajar. Bagi peneliti selanjutnya yang akan mengadakan penelitian sejenis, disarankan untuk menggunakan angket terbuka agar bisa 
mendapatkan jawaban yang lebih luas dari responden. Peneliti selanjutnya hendaknya menggunakan subjek penelitian yang lebih luas serta berbeda untuk mengetahui apakah penggunaan media tutorial $M Y O B$ berbasis Adobe Captivate memberikan hasil penelitian yang sama apabila diterapkan pada subjek yang berbeda. Di samping itu juga disarankan agar pengukuran kemandirian belajar dapat dilakukan baik pada kelas kontrol maupun kelas eksperimen.

\section{DAFTAR RUJUKAN}

Aripin. 2009. Step by Step Membuat Video Tutorial Menggunakan Camtasia Studio. Bandung: Oase Media.

Arsyad, Azhar. 2007. Media Pembelajaran. Jakarta: Rajagrafindo Persada.

Erfan, Mohammad. 2009. Pengembangan Media Pembelajaran Tutorial Corel

Draw dalam Mata Pelajaran Teknologi Informasi dan Komunikasi

kelas VIII SBI di SMP Negeri 4 Kepanjen. Skripsi tidak diterbitkan. Malang:

Universitas Negeri Malang.

Hamalik, Oemar. 2008. Perencanaan Pengajaran Berdasarkan Pendekatan Sistem. Jakarta: Bumi Aksara.

Hidayati, Kana dan Endang Listyani. Pengembangan Instrumen Kemandirian Belajar Mahasiswa. Jurnal Pendidikan. Vol. 4 No. 1. 1-15. September 2009, (online), (http://staff.uny.ac.id/sites/default/files/penelitian/kana-hidayati,mpd/pengembanganinstrumen.pdf, diakses tanggal 10 Februari 2012).

Miarso, Yusuf Hadi. 2005. Menyemai Benih Teknologi Pendidikan. Jakarta: Kencana.

Munadi, Yudhi. 2010. Media Pembelajaran: Sebuah Pendekatan Baru. Jakarta: Gaung Persada Press.

Nasution, S. 2010. Berbagai Pendekatan dalam Proses Belajar dan Mengajar. Jakarta: Bumi Aksara.

Pujiantoro, Wirawan. 2011. Pengembangan Media Tutorial Berbasis Multimedia Interaktif pada Mata Pelaaran Teknologi Informatika Kelas VIII Semester II di SMP Negeri 1 Mojosari. Skripsi tidak diterbitkan. Malang: Universitas Negeri Malang.

Sadiman, Arief, dkk. 2010. Media Pendidikan: Pengertian, pengembangan dan pemanfaatannya. Jakarta: Rajagrafindo Persada.

Sidik, Fajar. 2010. Pengembangan Media CD Tutorial Pembelajaran Menggunakan Software Camtasia Studio 6.0 Pada Mata Pelajaran TIK Pokok Materi Internet Untuk Kelas IX MTs. Wahid Hasyim 02 Dau Kabupaten Malang. Skripsi tidak diterbitkan. Malang: Universitas Negeri Malang.

Sudjana, Nana. 2005. Penilaian Hasil Proses Belajar Mengajar. Bandung: Remaja Rosdakarya.

Sugiyono. 2010. Metode Penelitian Pendidikan: Pendekatan Kuantitatif, Kualitatif, dan $R \& D$. Bandung: Alfabeta.

Syah, Muhibbin. 2010. Psikologi Pendidikan: dengan Pendekatan Baru. Bandung: Remaja Rosdakarya.

Wena, Made. 2009. Strategi Pembelajaran Inovatif Kontemporer: Suatu Tinjauan konseptual operasional. Jakarta: Bumi Aksara. 